\title{
Seniors overmedicalized, experts say
}

$\mathrm{S}$ eniors in Canada are overdrugged and overtested, to the detriment of both their health and the health care system, as billions of dollars are being spent that could more productively be spent elsewhere, several experts say.

An array of factors is contributing to the overmedicalization of seniors, the experts add, including a simple desire of many patients for pharmaceutical solutions to prolong life or improve sexual performance; drugging seniors to make them manageable in health facilities; overuse of preventive medication; aggressive pharmaceutical industry marketing techniques; questionable clinical guidelines; and prescriptions to offset the effects of other prescriptions.

Pharmacists filled an average 74 prescriptions per year for people aged 80 or over in 2005 , as compared to 14 prescriptions per year for all other age groups, according to the latest available Statistics Canada data. The Canadian Institute for Health Information (CIHI) says that in 2010 , about $13 \%$ of seniors who took five or more prescription medications experienced a side effect that caused them to seek further health care services.

CIHI says that drug expenditures in Canada increased from $\$ 3.8$ billion in 1985 to $\$ 31.1$ billion in 2010 and that per capita drug spending among seniors is three times that of the rest of the population. There was a $214 \%$ increase in the prescription drug claims by Ontario seniors between 1997 and 2006, during which time there was an $18.5 \%$ increase in the number of people aged over 65 (BMC Family Practice 2010;11:75). $\mathrm{CIHI}$ data indicate that the number of seniors on public drug programs taking five or more drug classes increased from $57.7 \%$ to $62.0 \%$ from 2002 to 2008 .

All of those numbers suggest that there are major challenges for the health care system, including costs, says Dr. Margaret McGregor, a family physician at the Mid-Main Community Health Centre in Vancouver, British Columbia. "Certainly, we are pushing up our life expectancy. The question is,

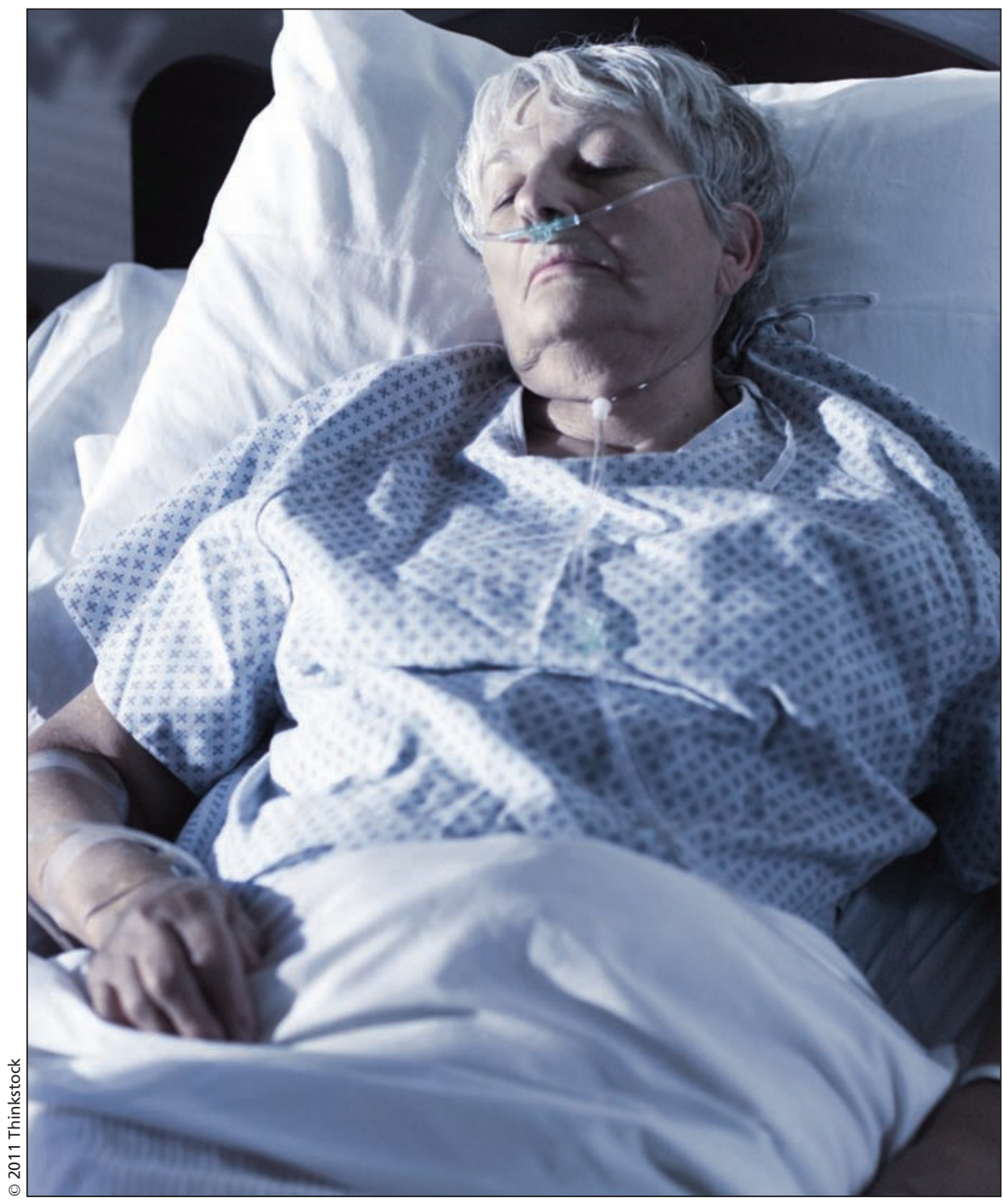

Canadian Institute for Health Information data indicate that per capita drug spending among seniors is three times that of the rest of the population.

in doing expensive things at the margins, what other opportunities are we missing out on?"

Among the great culprits is unnecessary preventive medication, McGregor says. "We tend to keep elderly people on medications for prevention purposes, even when there's no real research that supports doing so."

Some drugs that are prescribed to the elderly can be harmful to their health, says Dr. Fernand Turcotte, a retired physician and cofounder of the Department of Preventive and Social
Medicine at the Universite du Laval in Québec City, Quebec.

For example, Turcotte says, hypertensive drugs are counterintuitive for many elderly patients. After age 75 or 80 , the arterial walls are less elastic and therefore a higher blood pressure is often necessary to pump blood to areas where it's needed, he says. "By medicating to lower blood pressure, I run a high risk of creating circulatory insufficiency."

Turcotte argues that many prescriptions for the elderly are entirely unnecessary. "When we look at long term 
health care facilities in Quebec, many people are still receiving statins? What the hell are we trying to prevent?"

Some physicians have argued that ageism in medicine leads to preventive prescriptions that cannot be correlated to either longevity or quality of life (BMJ 2010; 341: 181).

The prescribing pressures come not only from the internal medical community that strives for equal treatment for all, but also from the patients themselves. As Turcotte explains, families ask physicians to do whatever they can to reduce the pain of elderly loved ones. In addition, direct-to-consumer marketing is leading baby boomers on a quest for youth to ask for prescriptions for "lifestyle" drugs like Viagra or hormone replacement therapy, he argues.

Still others say that the pharmaceutical industry plays a role. "Doctors are influenced [by pharmaceutical marketing] usually without knowing it," says Dr. Joel Lexchin, professor of health policy at York University in Toronto, Ontario. Lexchin adds that his studies link marketing with decreased quality in prescribing patterns and increased costs for patients, including seniors (PLoS Med 7(10): e1000352. doi:10.1371/journal.pmed .1000352).

McGregor says clinical practice guidelines are another contributing factor. Guidelines are often set by diseasefocused experts, who don't factor in such considerations as the impact of interventions on overall patient health, and don't consider the financial consequences on the health care system.

"Once you've diagnosed so many heart attacks, you get a skewed version and see heart attacks everywhere," she argues. "It's not a broad discussion of the population impact."

Turcotte says guideline writers are often "corrupted by conflicts of interest" and have their research supported by pharmaceutical firms, while physicians are often blinded by the fact that the guidelines were written by the "celebrities of various specialties," people who are considered too powerful for other doctors to challenge.

Lexchin argues the aging process itself often leads to unnecessary interventions. Normal reactions associated with aging, such as depression or grief or even sadness and isolation associated with being cooped up indoors during the winter are often inappropriately characterized as medical conditions, he says. "Doctors don't have a lot of time to spend with each patient, nor do they often have access to the kind of resources like social workers and community workers that could prevent the use of prescription medications."

More insidiously, Lexchin argues that the elderly in long term care homes are often drugged so that they are more manageable in a resource-constrained environment. He cites as evidence a study that found about a quarter of adults who enter a licensed nursing home in the province of Ontario were prescribed an antipsychotic drug in their first year, despite never having been on a neuroleptic ( $\mathrm{J}$ Am Geriatr Soc 2004; 52:749-55).

Others say that seniors themselves are driving the overmedicalization trend. That's especially the case for those seeking to maintain their level of sexual activity, says Turcotte. "To add insult to injury we're trying to do the same thing for females by creating the false disease of female sexual dysfunction."

McGregor says the financial consequences of overmedicalization are enormous for the health care system and for treatment of seniors. "We could put that money into more human resources, better food and more programs [in long term care homes]," she argues. Wendy Glauser, Toronto, Ont.

CMAJ 2011. DOI:10.1503/cmaj.109-3886

Editor's note: Sixteenth of a series on end-of-life care

Part I: Preparing for the inevitable (www.cmaj.ca/lookup/doi/10.1503/cmaj.109-3704)

Part II: Advance directives: Obstacles in preparing for the worst (www.cmaj.ca/lookup/doi/10.1503/cmaj.109-3743)

Part III: End-of-life planning framework calls for fewer checklists, more conversation (www.cmaj.ca/lookup/doi/10.1503/cmaj.109-3746)

Part IV: Tools help patients tackle tough choices for end-of-life care (www.cmaj.ca/lookup/doi/10.1503/cmaj.109-3750)

Part V: National home care standards urged

(www.cmaj.ca/lookup/doi/10.1503/cmaj.109-3731)

Part VI: Access to palliative care varies widely across Canada (www.cmaj.ca/lookup/doi/10.1503/cmaj.109-3763)

Part VII: Framework urges physicians to proceed with caution on palliative sedation (www.cmaj.ca/lookup/doi/10.1503/cmaj.109-3766)

Part VIII: Pocket-sized help for people with dementia (www.cmaj.ca/lookup/doi/10.1503/cmaj.109-3705)

Part IX: Grief therapy for those left behind

(www.cmaj.ca/lookup/doi/10.1503/cmaj.109-3793)

Part X: Providing hospice in the womb (www.cmaj.ca/lookup/doi/10.1503/cmaj.109-3776)

Part XI: Providing palliative care to the homeless

(www.cmaj.ca/lookup/doi/10.1503/cmaj.109-3756)

Part XII: England examines funding options for end-of-life care

(www.cmaj.ca/lookup/doi/10.1503/cmaj.109-3849)

Part XIII: Paramedic program reducing emergency room congestion (www.cmaj.ca/lookup/doi/10.1503/cmaj.109-3897)

Part XIV: Legal ambiguities surround authority to make end-of-life decisions (www.cmaj.ca/lookup/doi/10.1503/cmaj.109-3910)

Part XV: "Seniors emergency departments" yield health improvements, advocates say (www.cmaj.ca/lookup/doi/10.1503/cmaj.109-3868) 